\title{
Evaluation of story response in seismic prone building construction using high damping rubber bearing
}

\author{
Evaluación de la respuesta del piso en la construcción de edificios propensos a sismos con un \\ cojinete de hule de alta amortiguación
}

\author{
A. B. M. Saifull Islam (Main and Corresponding Author) \\ Department of Civil \& Construction Engineering, College of Engineering \\ Imam Abdulrahman Bin Faisal University, 31451 Dammam (Saudi Arabia) \\ asislam@iau.edu.sa
}

Manuscript Code: 893

Date of Acceptance/Reception: 17.03.2018/21.03.2017

DOI: 10.7764/RDLC.17.3.354

\begin{abstract}
Significantly growing construction in the earthquake vulnerable regions needs appropriate handling of seismic prone buildings. Insertion of high damping rubber bearing (HDRB) at the building base might be an attractive option for structural safety and economy. This study deals with incorporation of HDRB device in building base and focus on the change of structural behavior for its different categories. Structural responses of base isolated (BI) buildings under site- specific seismic excitation are analyzed. The superstructure of multistoried buildings is represented by a finite element (FE) model comprising multi-degree of freedom. The structural analyses involve the BI as well as fixed base (FB) buildings. The commercial finite element packages SAP 2000 has been used to determine the variation in structural responses performing static and dynamic analyses. Twenty prototype building frames are modelled considering four HDRB categories. The HDRB is found to make the buildings more flexible reducing the seismic responses. The increased natural period leads more importance of building flexibility effects and so the horizontal shift of superstructure increases. The story shear reduces significantly and eventually the reduced overturning moment indicates that the forces are highly overestimated if the bearing is not employed. The acceleration profile presents good agreement with the isolation strategy. Without bearing, story accelerations will be largely glorified. To lessen corresponding story shears and story accelerations HDRB can be chosen as per the specifications and necessities. Such HDRB isolated buildings can withstand rather high seismic tremors in a safe and efficient manner due to radical reduction of story responses and good structural flexibility.
\end{abstract}

Keywords: Seismic isolation; structural retrofitting; dynamic analysis; high damping rubber bearing; seismic prone building, story response.

Resumen

Aumentar significativamente la construcción en las regiones vulnerables a los terremotos requiere una gestión adecuada de los edificios con una tendencia sísmica. La inserción de un cojinete de hule de alta amortiguación (HDRB) en la base del edificio podría ser una opción atractiva para la seguridad estructural y la economía. Este estudio se ocupa de la incorporación del dispositivo HDRB en la base de construcción y se centra en el cambio de comportamiento estructural para sus diferentes categorías. Se analizan las respuestas estructurales de los edificios de base aislada (BI) bajo excitación sísmica específica del sitio. La superestructura de los edificios de varias plantas está representada por un modelo de elementos finitos (FE) que comprende múltiples grados de libertad. Los análisis estructurales involucran tanto los edificios de BI como los de base fija (FB). Los paquetes de elementos finitos comerciales de SAP 2000 se han utilizado para determinar la variación en las respuestas estructurales mediante la realización de análisis estáticos y dinámicos. Veinte prototipos de marcos de edificio se modelan considerando cuatro categorías de HDRB. Se encuentra que el HDRB hace que los edificios sean más flexibles, reduciendo las respuestas sísmicas. El aumento del período natural le da más importancia a la flexibilidad del edificio y, por lo tanto, aumenta el desplazamiento horizontal de la superestructura. La cizalladura de la historia se reduce significativamente $y$, finalmente, el momento de vuelco reducido indica que las fuerzas están sobrestimadas en gran medida si no se utiliza el rodamiento. El perfil de aceleración presenta un buen acuerdo con la estrategia de aislamiento. Sin cojinete, las aceleraciones de piso serán ampliamente glorificadas. Para reducir las cizallas de piso y las aceleraciones de piso correspondientes, se puede elegir HDRB, según las especificaciones y necesidades. Tales edificios aislados por HDRB pueden resistir temblores sísmicos bastante altos de una manera segura y eficiente debido a la reducción radical de las respuestas del piso y una buena flexibilidad estructural.

Palabras clave: Aislamiento sísmico, retroadaptación estructural, análisis dinámico, cojinete de hule de alta amortiguación, edificio propenso a sismos, respuesta de piso.

State of the art

During the occurrences of earthquakes, extreme ground excitation and seismic motion can cause severe damage to structures. The vulnerability of structures to seismic damage has been highlighted by numerous recent earthquakes around the world. They cause inertia forces on the building structures which is functions of ground accelerations induces by earthquake and the building mass. When the ground acceleration enhances, it is obvious that the strength capacity of the structure must be augmented to prevent the structural damage. However, continuous increase of building strength indefinitely is not practical. The acceleration forces affecting building in seismic vulnerable region may surpass gravitational acceleration up to two times. It is neither easy nor economic to design seismic prone buildings for this level 
of strength. Conversely, rather than increasing the strength capacity, seismic base isolation can give a potential solution of this problem by offering reduction of response demand. Even though the occurrence of natural earthquake cannot be controlled, its influence on structure can be mitigated by averting the motions transmission from the substructure towards the superstructure. The isolation system provides additional flexibility as well as energy dissipation capability by coming between the superstructure and foundation of a building (Ismail, Rodellar, \& Ikhouane, 2010).

The performance of high damping rubber bearings (HDRB) brought a contemporary aspect to analyze and design base isolated (BI) structures (Islam, Jameel, Jumaat, \& Rahman, 2013). Dicleli and Buddaram (Dicleli \& Buddaram, 2007) assessed equivalent linear analysis technique for BI structures signified by sinle degree of freedom (SDOF) systems. Casciati and Hamdaoui (Casciati \& Hamdaoui, 2008) simulated the response of a base isolation system. Islam, Jameel, Uddin, and Jumaat (2012) introduced the proficient Building elevation for using isolation system in seismic vulnerable buildings. Tornello \& Sarrazin (2012) have dealt with the behavior of BI building using high damping spring system under near fault earthquakes. Bhuiyan, Okui, Mitamura, \& Imai (2009) introduced HDRB rheology model to analyse the seismic effects as well as the identification of nonlinear viscosity. Chaudhary, Abé, \& Fujino (2001) evaluated the seismic performance of BI Yama-agé bridge with HDRBs using recorded seismic data. Markou and Manolis (2016) have worked on mechanical models for shear behavior in HDRB. Alhan, Gazi, \& Kurtuluş (2016) investigated the importance of stiffening of HDRBs on the structural responses of BI buildings imposed by near-fault earthquakes.

Although the usage of isolators may be well known in many parts of the world, an extensive lack of appropriate research is there for the practical implementation of high damping rubber bearing devices to be inserted on building structures as per the site-specific ground excitation accordance with the local requirements. Actual field in-situ earthquake considerations have rarely been done. The time history analysis for dynamic response investigation is lengthy and expensive in computation. Apart from this, response spectrum analysis is somewhat prompt, succinct, and inexpensive (Leng, Chintanapakdee, \& Hayashikawa, 2014) rather than experimental alternatives in different ways to meet the growing structural needs (Huda, Jumaat, Islam, \& Soeb, 2016; Rahman, Jumaat, Hosen, \& Islam, 2016). Due to advancements in computer software and hardware, it has become easier to conduct the numerical investigation (Islam, Hussain, Jameel, \& Jumaat, 2012; Ky, Lenwari, \& Thepchatri, 2015) precisely.

\section{Description of the problem}

As can be expected, there should be a mitigation of structural responses associated with isolation which can ensure economic alternative. It can make sense to incorporate with benefits if the consequence is smarter compared to the available schemes to ensure seismic resistance. Therefore, the intention of the research is to evaluate the viability of using rubber bearing isolation devices at the structural base of buildings. To meet up the target, HDRB models have been incorporated in building bases. Equivalent static analyses as well as dynamic analyses have been carried out inserting isolators for different configurations of structures. Design parameters for the isolators along with the structural responses of several buildings of different number of stories are assessed. story shear behavior of fixed base (FB) and $\mathrm{BI}$ buildings have been evaluated. Furthermore, the story acceleration of the selected buildings has been appraised which might ensure the potential of selecting the HDRB in building construction.

\section{Methodology}

The RCC building frames modelled vary from 4 to 10 stories tall. The superstructure is simulated as a reinforced concrete moment resisting frame (MRF). The buildings of study are multistoried residential buildings. Static analyses are carried out initially to get the required loading for the isolation design. Base isolators are designed and evaluated for all variations of the studied building. The isolators are attached at base level to confirm all the properties in spring.

\section{Hypothesis of structural system}

Four moment resisting frame buildings of 4 bays @ 7.62m at $x$ and $y$ directions looking square plan with gradual increase of numbers of stories 4 (four), 6 (six), 8 (eight) and 10 (ten) story shown in Fig. 1 have been chosen for the present assessment. For every individual building, the total seismic weight is disseminated in equal manner over all the floors. Four types of HDRB system have been incorporated at infinitely rigid structural base for all the buildings leading total number of 16 models. The building specifications are: $f y=414 \mathrm{MPa}, \mathrm{f}^{\prime} \mathrm{c}=28 \mathrm{MPa}$, slab thickness $=150 \mathrm{~mm}$, imposed dead load $=4.8 \mathrm{KPa}$ and live load $=2.4 \mathrm{KPa}$. For the conventional state, the building natural time periods are $0.50(4$ Story), 0.75 (6 Story), 0.80 (8 Story) and 1.00 (10 Story). 


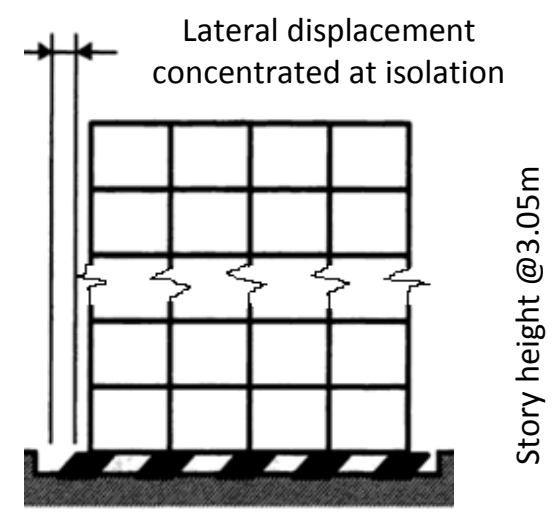

\section{Incorporation of HDRB}

The HDRB isolators were designed according to the procedure mentioned by Kelly, Robinson \& Skinner (2006). A computer code, HDRB-NONLIN, was developed for the design of high damping rubber bearing. The code maintains iterative computation for stiffness, damping, strength, displacement etc. considering the seismic data, imposed loading and bearing specifications. The bearings were connected at each column bottom. The higher shear strain limit for HDRB ensure smaller plan sizes. Because of its large vertical stiffness, heavy structural loads can be carried by HDRB (Islam, 2018; Islam, Ahmad, Jumaat, Hussain, Rahman, \& Darain, 2014). Dynamic analyses of the three-dimensional (3D) buildings were carried out with consideration for the associated nonlinearities. The characteristics of the materials used for the isolators as given in the design data sheet have been shown in Table 1.

The isolators were designed with consideration for vertical loads, categories of bearings as well as dissimilar properties using the developed Excel program tool, HDRB-NONLIN. The considerations are mentioned in the subsequent sections with proper evidence. Damping was varied for different bearings. HDRB were assigned to the building columns' base. The elastomer properties of the bearings and the isolator types have been as shown in Table 3 .

The mentioned data types varied according to the type of isolator being assessed. Here, the variation of HDRB types of isolators was considered. The HDRB isolators have been demarcated by the circular shape, size of its plan, configurations of rubber layers as well as steel plates. Starting values are selected for project performance specifications as:

The HDRB is composed of thin layers of high damping rubber as well as steel plates fabricated alternatively. The low shear modulus of the elastomers controls the bearing's horizontal stiffness. Furthermore, high vertical stiffness is the contribution of steel plates which obviously preclude rubber bulging. Lower horizontal stiffness of HDRB device ensures the natural periods to be higher. High nonlinearly of stiffness and energy dissipation is the salient behavior of HDRB which is relying on shear strain. Here, bearing's effective horizontal stiffness is contemplated in terms of $K_{r}$ (Post-elastic stiffness). The bearing's force-deformation has been considered in the modelling as equivalent linear. The shape of force-deformation of HDRB under loading is shown in Fig. 2. Considering reduced rubber area as $A_{r}$ and total rubber thickness $T_{r}$, the $K_{r}$ has been derived as Eq. (1).

$$
K_{r}=\frac{G_{\gamma} A_{r}}{T_{r}}
$$

The hysteresis loop area obtained for the respective shear modulus and equivalent viscous damping provides the hysteresis. The $G_{\gamma}$ ( shear modulus) is the function of shear strain. The unloading stiffness named as elastic stiffness, $K_{u}$ is defined as Eq. (2):

$$
K_{u}=K_{r}
$$

Moreover the force intercept, $Q$ follows the Eq. (3) which is estimated from effective stiffness, damping 6 , design basis displacement, $\Delta$ and yield displacement, $\Delta_{y}$ (Cheng, Jiang, \& Lou, 2008). 
Figure 2. Deformation pattern of HDRB. Source: Self-Elaboration (2018).

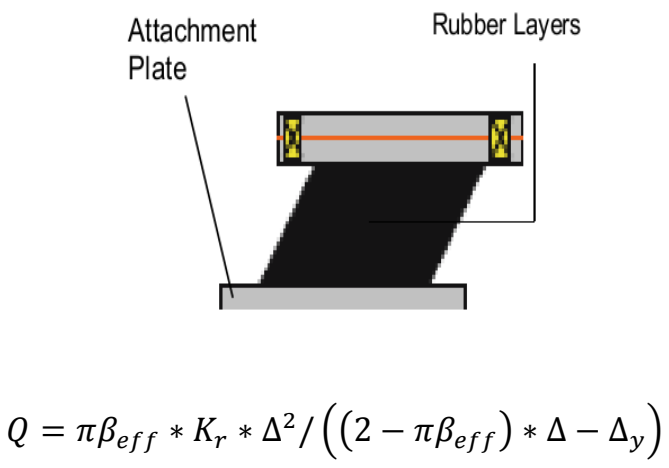

\section{Dynamics of structural system}

Simple linear static analyses have been carried out with minimum complexity level in the study. The lateral loads for ground excitation are obtained from the seismic zone factor, structural importance factor, response modification factor, soil Profile etc. The lateral shear for wind loading has been determined from the related coefficients and code requirement. The specifications for earthquake and wind analysis follow the code UBC 1997 (Uniform Building Code (UBC), 1997).

The prototype buildings have been simulated and loaded employing the finite element package SAP 2000 (CSI, 2004 ). The equivalent static analysis have been carried out adopting UBC 1997 (Uniform Building Code (UBC), 1997) for the traditional FB buildings with $R_{I}=8.0$. On the other hand, a reduced response modification factor $R_{I}=2.0$ has been considered for the base isolated building responses while the structural importance coefficient is 1.0 as per occupancy category (Uniform Building Code (UBC), 1997).

Dynamic analysis in the study carried out in the study is response spectrum analysis (RSA). The RSA is conducted for FB structures initially to ascertain the effective analysis type than equivalent static scheme. The structures are then linked to the isolator system. The properties of the isolators at their respective column bases were taken from the isolation system design and used to again carry out dynamic analyses.

The site-specific seismic record of Dhaka earthquake engendered from the recently occurred closest point has been chosen in the study for seismic analysis. The design smooth response spectra (Islam, Jameel, Ahmad, Salman, \& Jumaat, 2011) of this selected earthquake for fixed and base isolated conditions are displayed by Figure 3 where the spectrum has been reduced for $\mathrm{BI}$ case by damping coefficient after 2.5 second isolation period.

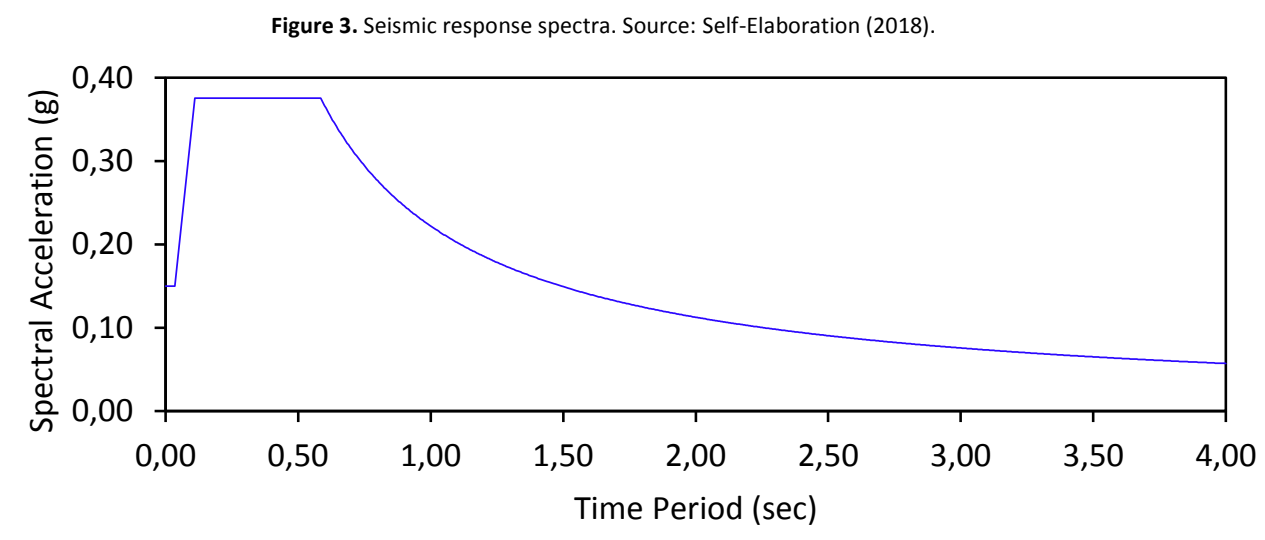

a) Response spectrum for FB building 


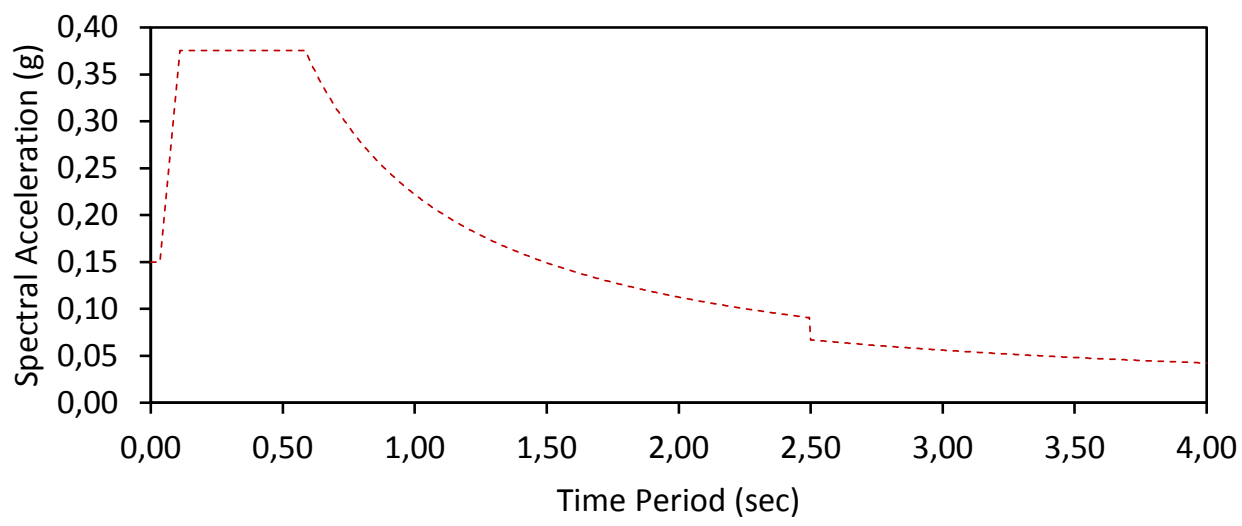

b) Composite response spectrum for BI building

The equation for motion of the building super structure after the bearing insertion can be designated by means of in Eq. (4). The equation is as follows.

$$
[M]\left\{\ddot{y}+\ddot{y}_{b}\right\}+[C]\{\dot{y}\}+[K]\{y\}=-[M]\left[T_{g}\right]\left\{\ddot{y}_{g}\right\}
$$

In the dynamic equation, $[K]$ is the stiffness matrix; $[C]$ is the damping matrix and $[M]$ is the mass matrix of the building superstructure for the slabs' respective degrees of freedom (DOF). $\left[T_{g}\right]$ is the matrix of earthquake influence coefficient. In addition, $\{y\}=\left[y_{x}, y_{y}, y_{z}\right]^{T}$ is the displacement vector at the floor levels of the structure associated with the base mass; $\left\{y_{b}\right\}=\left[y_{b x}, y_{b y}, y_{b z}\right]^{T}$ is the base displacement vector connected to the ground and $\left\{\ddot{y}_{g}\right\}$ is the vector of ground acceleration.

The dynamic scheme of analysis has been covered by response spectrum analysis following the prescribed dynamic procedure. This analysis technique uses the design response spectra generated from seismic excitation in case of fixed base buildings. However, for the base isolated buildings, the design response spectrum has been modified to cope with the damping provided by the bearings by using a composite spectrum. A factor named $\mathrm{B}$ factor has been used to reduce the $5 \%$ damped composite spectrum in the isolated modes (Figure 3 ).

The selected response analysis approach is economic in computation to forecast the displacements, velocity as well as ground accelerations for the building structures. The equations of motion have been transferred for the dynamic analysis into a normal coordinate system. Modal superposition technique is employed to perform the response spectrum analyses. The values of modal superposition have been combined according to the complete quadratic combination (CQC) approach. The SRSS progression provides the directional combination. In the response spectrum method, the practice of such modal superposition technique is applicable for dynamic analysis.

\begin{tabular}{lcc}
\multicolumn{3}{c}{ Table 1. Salient features of HDRB. Source: Self-Elaboration (2018). } \\
\hline Parameter & Unit & Value \\
\hline Properties of rubber & $\mathrm{KPa}$ & 1350 \\
Elastic Modulus & $\mathrm{KPa}$ & 400 \\
Shear Modulus & & 0.87 \\
Material Constant & $\%$ & 650 \\
Ultimate Elongation & & \\
Designed properties of HDRB & & Circular \\
Shape & & 25 \\
No. of bearings & $\mathrm{mm}$ & 950 \\
Diameter & $\mathrm{mm}$ & 10 \\
Rubber layer thickness & $\mathrm{mm}$ & 40 \\
Height of cover plate & & \\
\hline
\end{tabular}




\section{Computer aided study}

A total of four variations of HDRB isolation system have been considered for each of four buildings of varying height to meet the present investigation. The bearing designs are accomplished with the developed Excel program tool, HDRBNONLIN. All the isolation systems are designed to satisfy the stiffness and strength properties essential for the assessment.

The basis to design the bearings is seismic load comprising the factors considering the soil profile and ground excitation as described. The implemented design spectrum is shown in Figure 3. Each isolation system has been designed for isolation effective periods of 1.5, 2.0, 2.5 and 3.0 seconds maintaining them within the customary range of isolation system period. By and large, the longer the isolation period the more flexible the structures are.

The properties of HDRB are functions of shear strain applied with around $3 \mathrm{MPa}$ shear modulus for very little strains dropping to $0.75 \mathrm{MPa}$ at $250 \%$ strain. Yield displacements, $\Delta y$, is chosen as 0.05 to 0.10 times the thickness of rubber. The damping percentage ranges from $15 \%$ to $19 \%$ relying on the individual isolation periods. The variations of bearing properties and the hysteresis parameters to be employed for the modelling and analyses are illustrated in Table 2.

Table 2. Various bearing device properties. Source: Self-Elaboration (2018).

\begin{tabular}{lccccc}
\hline Parameter & Unit & \multicolumn{4}{c}{ Value } \\
\hline Bearing Device & & HDRB1 & HDRB2 & HDRB3 & HDRB4 \\
Period of Isolator & sec & 1.5 & 2.0 & 2.5 & 3.0 \\
Damping & $\%$ & $15 \%$ & $16 \%$ & $17 \%$ & $19 \%$ \\
\hline
\end{tabular}

\section{Rationale of the investigation}

The selected buildings for isolation experienced structural time periods $\leq 1.0$ second which is considered a suitable value within reasonable limits (Kelly, Robinson, \& Skinner, 2006). The lateral loads (base shear) subjected to wind was clearly less than $10 \%$ of building weight (Deb, 2004) as required. Thus, isolators could be inserted at the structural base as an alternative to the conventional fixed base strategy.

The ability of isolation bearings to carry the loads was checked using satisfactory factors of safety. It is also supported as the HDRBs' factors of safety are within the recommended limits. The performance of the BI structures in both the cases of design basis earthquake (DBE) along with the maximum credible earthquake (MCE) have been found to be satisfactory. Furthermore, each value of maximum displacements remains within the allowable isolator design static displacement under MCE. Therefore, the properties of the HDRB devices maintain good agreement and can be reasonably employed.

Basic model for structural system of the authors have already been published (Islam, Hussain, Jameel, \& Jumaat, 2012; Islam, Hussain, Jumaat, \& Rahman, 2013). Similar building configuration has been chosen for the 10-story building as well as other seismic prone structure with identical environmental condition. The study extends the investigation as mentioned in detail to find out suitable alternative of high damping bearing system to be implemented in the structural base for getting better benefit.

\section{Results and Discussion}

The behavior of base isolated structure with HDRB is being changed because of the flexibility of superstructure movement offered by isolation. The structures-substructure contact part of the building structures allows the superstructure to move, thus reducing the seismic forces on the superstructure. Subsequent sections describe the improvement of structural responses and the variation for types of bearing.

\section{Evaluation of story shear}

Due to the ground excitation the building structure experiences huge horizontal shear in building base which effects on each story of the building. To design the structural members of different elevation it's a vital merit if the responses can be reduced. Therefore, one of the key tools to investigate the dynamic responses of base-isolated buildings are the story shear forces. The analysis results show that a significant amount of story shear can be lessened once high damping 
rubber bearing is inserted at base. Figure 4 shows that for FB structures, the story shears exist with quite larger value for almost all the story compared to the BI buildings. Here, "F" means floor or story. F0 is bottom story, F1 is 1st story and so on.

For low rise building the reduction of story shear is greater. For building with higher elevations, the rate of reduction is lower, but the amount of decrement is still noteworthy. This is because of structural flexibility offered by the high damping bearing which allows a structural shift horizontally and almost uniform story movement. At the isolation interface the structure gets trivial shear due to the bearing. For the top story of comparative high elevated building, the $\mathrm{BI}$ building shear is a bit greater than the case of no bearing due to the structural configuration.

Figure 4. Story Shears of FB and BI buildings. Source: Self-Elaboration (2018).
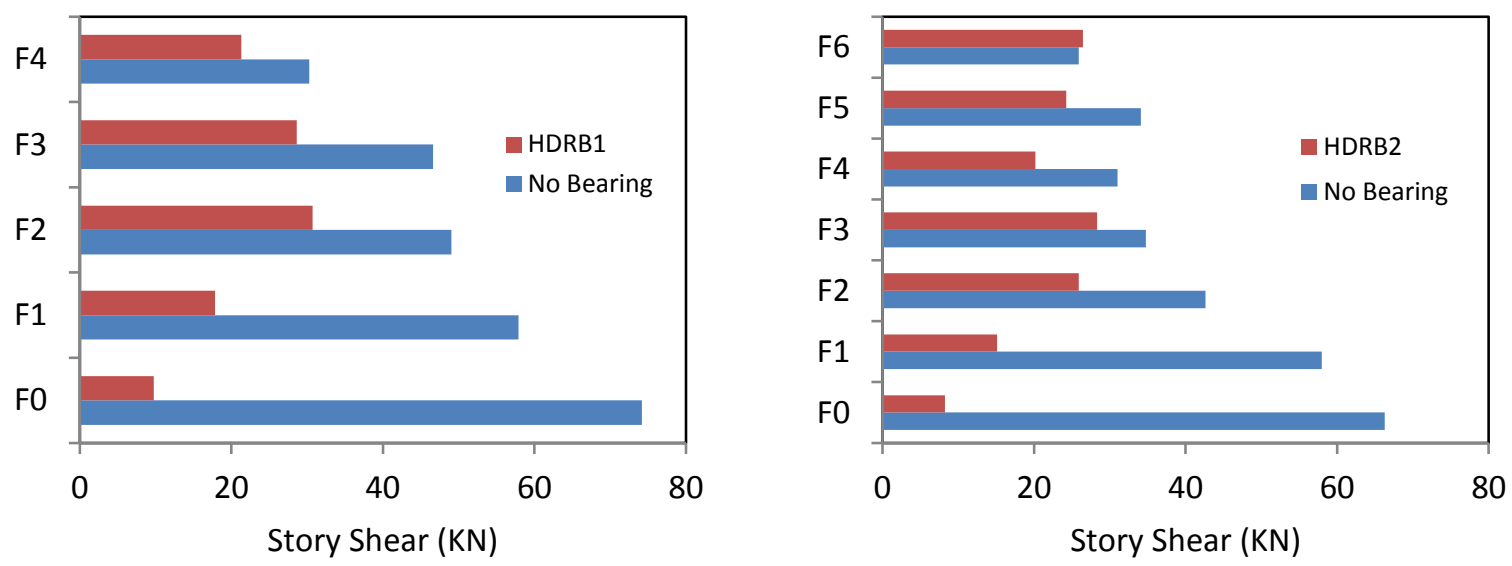

4 story building

6 story building

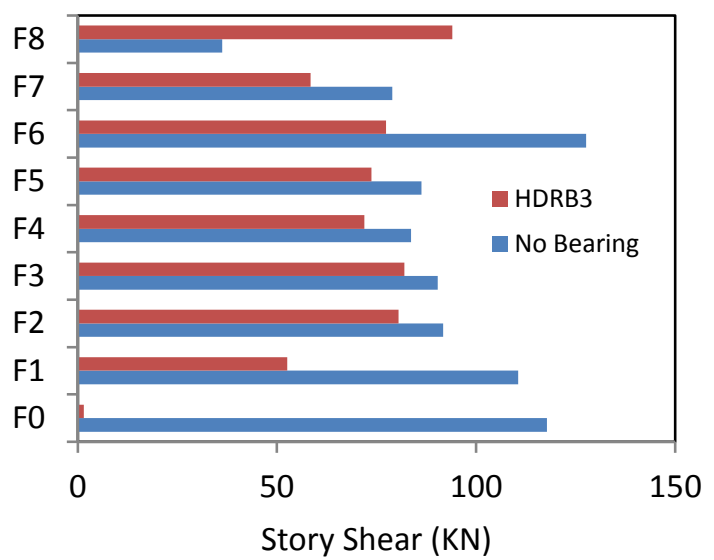

8 story building

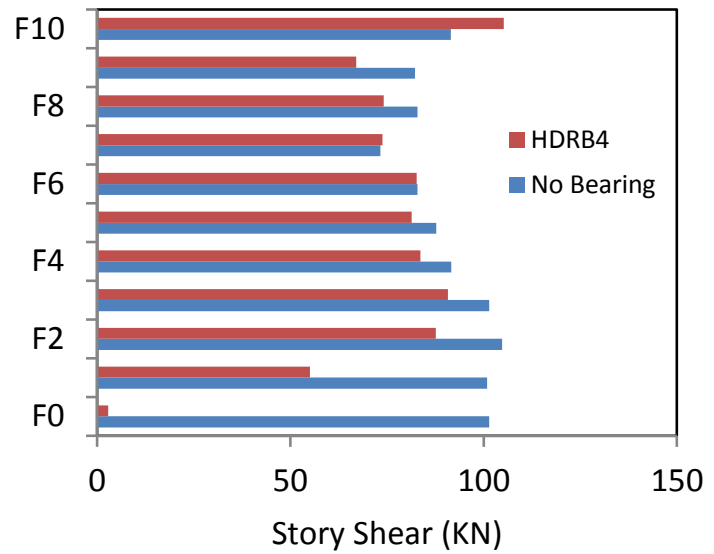

10 story building

\section{Evaluation of story acceleration}

Reduction of seismic damage by inserting bearing device is not only restricted to the structural system but also includes non-structural stuffs like building parts, components and contents. Diminishing non-structural damage is largely related to the lessening of story accelerations. Besides the maximum displacement of isolation systems and base shear coefficient another response indicator of $\mathrm{BI}$ buildings is the story lateral force in superstructure. Therefore, the distribution of story shear force as well as the superstructure height of the buildings has been focused as well. The indicator is chosen as story acceleration which is can be treated as normalized inertia force as well.

From the story accelerations, the inertia forces can also be obtained wherever the modal inertia force is the product of spectral acceleration, participation factor and the structural mass at the respective level. Figure 5 plots the behavior of story accelerations for different $\mathrm{BI}$ buildings each for single isolation period comparing with no bearing cases. The distribution of such story accelerations within the structural height defines ultimately the lateral forces at each level of the structure and eventually the total overturning moments on the building. 
The story accelerations (Figure 5) from the dynamic analysis are proportionate to inertia forces at the respective region. The accelerations for FB structures increase almost linear with height. The value of accelerations in these cases is equal to the maximum ground acceleration at base level which upsurges towards 3 to 6 times at roof level. The tendency of story acceleration increment is higher for low rise building and it is almost linear upsurge up to 6 story BI building. With the increase of number of stories, the variation becomes gradually nonlinear. And for high rise buildings, the shape of escalation is fully nonlinear. The rate of increment there is high up to the middle stories of the buildings, slight lower for a few stories and then again increases for top stories. However, for the $\mathrm{BI}$ buildings the story accelerations are continually lesser than the $0.154 \mathrm{~g}$ ground acceleration and there is no significant upsurge with height.

Figure 5. Story Accelerations of FB and BI buildings. Source: Self-Elaboration (2018).

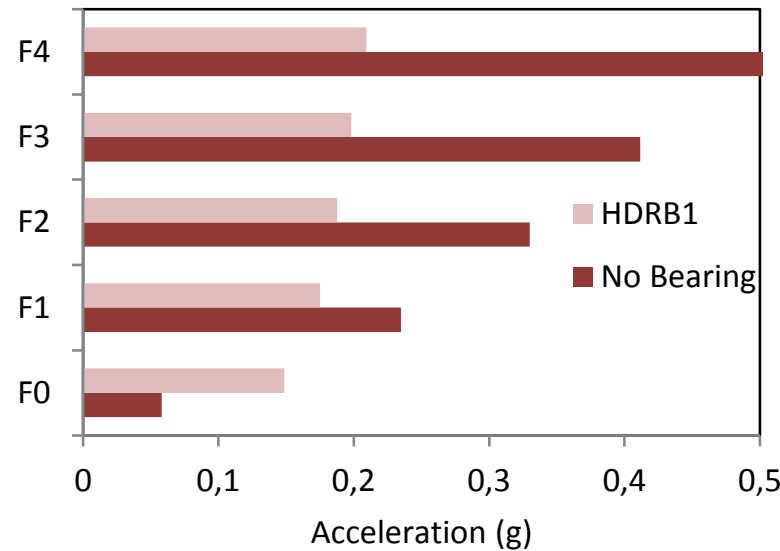

4 story building

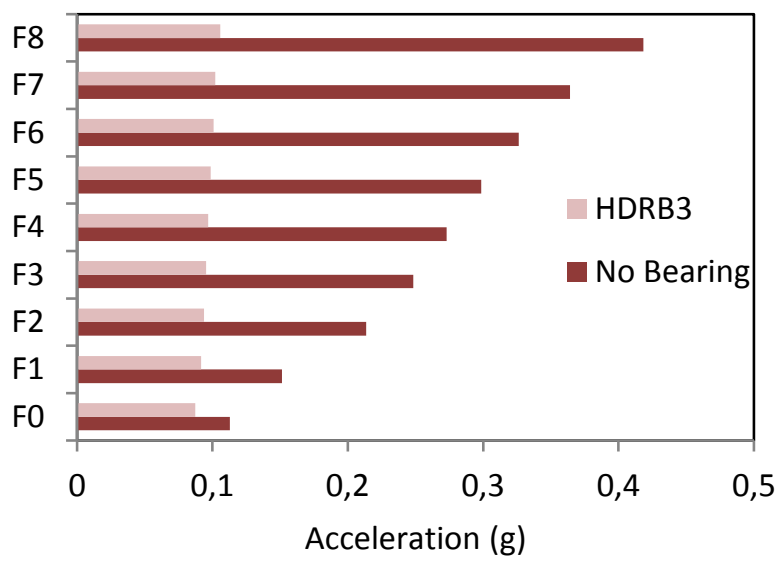

8 story building

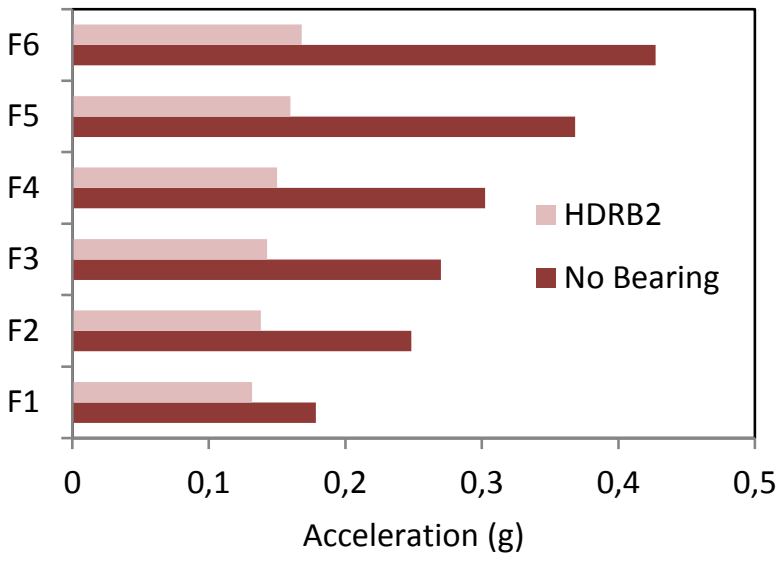

6 story building

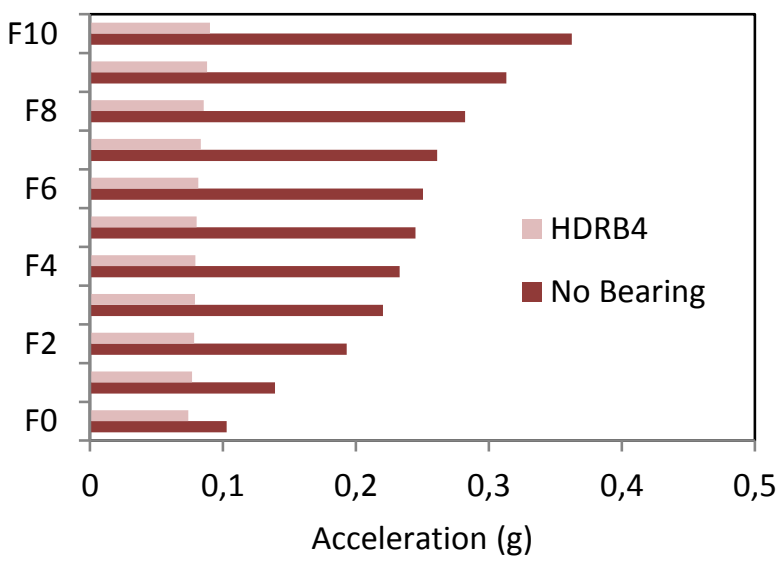

10 story building

From the story acceleration studies for different building with having individual natural period of vibration, it has been seen that the HDRB reflects the minimum values of accelerations and better uniformity for higher isolator period (HDRB4) to larger at lower isolation period. These are followed by variations of HDRB3, HDRB2 and HDRB1 in the selected bearing systems.

This is the elegance of inserting high damping rubber bearing that the story accelerations are almost uniform along the elevations which is recommended in isolation research. It is found that for the BI buildings, there is a radical reduction of accelerations especially at the upper stories. Very little deviation for the uniformity is due to the varying properties of HDRB devices as well as the equivalent damping ratio. Hence, the acceleration profile presents good agreement with the isolation strategy. If the bearing device is not inserted, the story accelerations especially at the upper stories will be largely overestimated. 
- The incorporation of high damping rubber bearing (HDRB) at structural base in seismic vulnerable area offers itself as a potential alternative of structural retrofitting.

- The HDRB system can excellently control the story shear of the buildings and hence the overturning moment indicating crucial enhancement leading to economic design.

- The reduction of story shear is larger for low rise building. For building with higher elevations, the rate of reduction is lower, but the amount of decrement is still noteworthy. This is because of structural flexibility offered by HDRB which allows a structural shift horizontally and almost uniform story movement.

- The story accelerations for FB building increase almost linearly with height. For increased number of stories, the variation becomes gradually nonlinear. However, HDRB induced story accelerations are almost uniform along the elevation. Besides, there is a radical reduction of accelerations especially at the upper stories. The acceleration profile presents good agreement with the isolation strategy. Without bearing, story accelerations will be largely overestimated.

- The HDRB reflects the smaller values of accelerations and better uniformity for higher isolator period to greater at lower isolation period.

- High damping bearing device can be chosen to reduce corresponding story responses. Selection of effective HDRB type depends on the site specifications and necessities.

\section{Acknowledgment}

The authors gratefully acknowledge the Project 2017-212-Eng, Deanship of Scientific Research (DSR), Imam Abdulrahman Bin Faisal University (IAU) for successful completion of the study.

Alhan, C., Gazi, H., \& Kurtuluş, H. (2016). Significance of stiffening of high damping rubber bearings on the response of base-isolated buildings under near-fault earthquakes. Mechanical Systems and Signal Processing, 79, 297-313. doi:http://dx.doi.org/10.1016/j.ymssp.2016.02.029

Bhuiyan, A. R., Okui, Y., Mitamura, H., \& Imai, T. (2009). A rheology model of high damping rubber bearings for seismic analysis: Identification of nonlinear viscosity. International Journal of Solids and Structures, 46(7-8), 1778-1792. doi:http://dx.doi.org/10.1016/j.ijsolstr.2009.01.005

Casciati, F., \& Hamdaoui, K. (2008). Modelling the uncertainty in the response of a base isolator. Probabilistic Engineering Mechanics, $23(4), 427-437$.

Chaudhary, M. T. A., Abé, M., \& Fujino, Y. (2001). Performance evaluation of base-isolated Yama-agé bridge with high damping rubber bearings using recorded seismic data. Engineering Structures, 23(8), 902-910. doi:http://dx.doi.org/10.1016/S0141-0296(00)00117-6

Cheng, F. Y., Jiang, H., \& Lou, K. (2008). Smart structures: innovative systems for seismic response control: CRC Press.

CSI. (2004). Linear and nonlinear static and dynamic analysis of three-dimensional structures In Computer \& Structures Inc. SAP 2000 (Ed.). Berkeley (CA): Computer \& Structures, Inc.

Deb, S. (2004). Seismic base isolation-an overview. Current Science, 87(10), 1426-1430.

Dicleli, M., \& Buddaram, S. (2007). Comprehensive evaluation of equivalent linear analysis method for seismic-isolated structures represented by sdof systems. Engineering Structures, 29(8), 1653-1663.

Huda, M. N., Jumaat, M. Z., Islam, A. B. M. S., \& Soeb, M. R. (2016). Influence of palm oil factory wastes as coarse aggregate species for high performance lightweight concrete. Revista de la Construcción, 15(3), 133-139.

Islam, A. B. M. S. (2018). Diminishing seismic effect on buildings using bearing isolation. IIUM Engineering Journal, $19(1)$, 59-71. doi:10.31436/iiumej.v19i1.844

Islam, A. B. M. S., Ahmad, S. I., Jumaat, M. Z., Hussain, R. R., Rahman, M. A., \& Darain, K. M. (2014). Efficient design in building construction with rubber bearing in medium risk seismicity: case study and assessment. Journal of Civil Engineering and Management, 20 (5), 621-631. doi:10.3846/13923730.2013.801910

Islam, A. B. M. S., Hussain, R. R., Jameel, M., \& Jumaat, M. Z. (2012). Non-linear time domain analysis of base isolated multi-storey building under site specific bi-directional seismic loading. Automation in Construction, 22, 554-566. doi:10.1016/j.autcon.2011.11.017

Islam, A. B. M. S., Hussain, R. R., Jumaat, M. Z., \& Rahman, M. A. (2013). Nonlinear dynamically automated excursions for rubber-steel bearing isolation in multi-storey construction. Automation in Construction, 30(0), 265-275. doi:http://dx.doi.org/10.1016/j.autcon.2012.11.010

Islam, A. B. M. S., Jameel, M., Ahmad, S. I., Salman, F. A., \& Jumaat, M. Z. (2011). Engendering earthquake response spectra for Dhaka region usable in dynamic analysis of structures. Scientific Research and Essays, 6(16), 3519-3530. 
Islam, A. B. M. S., Jameel, M., Jumaat, M. Z., \& Rahman, M. M. (2013). Optimization in structural altitude for seismic base isolation at medium risk earthquake disaster region. Disaster Advances, 6(1), 23-34.

Islam, A. B. M. S., Jameel, M., Uddin, M. A., \& Jumaat, M. Z. (2012). Competent Building Elevation for Incorporating Base Isolation in Aseismic Structure. Procedia Engineering, 50(0), 882-892. doi:10.1016/j.proeng.2012.10.096

Ismail, M., Rodellar, J., \& Ikhouane, F. (2010). An innovative isolation device for aseismic design. Engineering Structures, 32(4), $1168-1183$.

Kelly TE, Robinson WH, \& Skinner RI. (2006). Seismic Isolation for Designers and Structural Engineers: Robinson seismic Ltd.

Ky, V. S., Lenwari, A., \& Thepchatri, T. (2015). Optimum design of steel structures in accordance with AISC 2010 specification using heuristic algorithm. Engineering Journal, 19(4), 71-81. doi:10.4186/ej.2015.19.4.71

Leng, K., Chintanapakdee, C., \& Hayashikawa, T. (2014). Seismic Shear Forces in Shear Walls of a Medium-Rise Building Designed by Response Spectrum Analysis. Engineering Journal, 18(4), 73-95. doi:10.4186/ej.2014.18.4.73

Markou, A. A., \& Manolis, G. D. (2016). Mechanical models for shear behavior in high damping rubber bearings. Soil Dynamics and Earthquake Engineering, 90, 221-226. doi:http://dx.doi.org/10.1016/j.soildyn.2016.08.035

Rahman, M. M., Jumaat, M. Z., Hosen, M. A., \& Islam, A. B. M. S. (2016). Effect of adhesive replacement with cement mortar on NSM strengthened RC Beam. Revista de la Construcción, 15(1), 61-72.

Tornello, M. E., \& Sarrazin, M. (2012). Base-isolated building with high-damping spring system subjected to near fault earthquakes. Earthquakes and Structures, 3(3-4), 315-340.

Uniform Building Code (UBC). (1997). Earthquake regulations for seismic isolated structures. Paper presented at the International conference of building officials, Whitter (CA,USA). 